\title{
Musical Life in Urban Communities of North-Eastern Slovakia in the Period of Reformation
}

Janka Petőczová / janka.petoczova@savba.sk

Institute of Musicology of the Slovak Academy of Sciences, Bratislava, SK

\begin{abstract}
The musical culture in urban communities of the North-Eastern Slovakia from the mid-16th century can be searched on three basic issues: what changes in the musical culture were brought by Reformation in multi-ethnic and multi-confessional milieu; how was the musical life in major centres and in minor localities (cities) of Spiš and Šariš influenced by the development of Lutheran urban cantorates in Central Europe; what was the role of local (domestic) musicians in the cantorates (cantors, organists, trumpeters) within this process. The study deals with new findings in archival documents focused on personalities (J. Fabri, L. Stöckel, J. Plotz, G. Plotz) and their activities in the free royal cities and in smaller towns - the centres of musical life (Bardejov, Prešov, Levoča, Kežmarok, Spišská Nová Ves).
\end{abstract}

\section{Key words}

musicology, history of musical culture, Lutheran urban cantorates, Johann Fabri, Leonard Stöckel, Johann Plotz, Georg Plotz 
The research of the musical culture in urban centres of North-Eastern Slovakia (northern part of the historical Hungarian Kingdom) during the period of Reformation (15401674) has been within the Slovakian historiography chronologically classified as part of the Early Modern Period (1526-1711). ${ }^{1}$ The defeat of the Hungarian army at the battle of Mohacs on 29 August 1526 by Ottoman-Turkish troops resulted in disintegration of the Hungarian Kingdom and in relocating of many centres of cultural life into untouched regions of Upper Hungary and Transylvania. This process went in parallel with the emergence of Humanism and Reformation in Europe, with direct impacts on the further cultural and social development of the said regions.

The threat of the Turkish expansion has been present during the whole time of the constitution and strengthening of the Habsburg monarchy, as well as the process of denominationalisation within the religious communities. On one hand the status of Reformed Church congregations (mainly moderate, Evangelical) increased, on the other hand the recatholisation efforts of the Habsburgs gained momentum. Confessional ambitions constituted one of the reasons of the anti-Habsburg uprisings, led by influential Hungarian noblemen (Bocskay, Bethlen, Rákóczi, Wesselény, Thököly). The recatholisation reached its peak in the years of 1673-1674 with the trials of Evangelical pastors followed by their persecution. The aftermath of the recatholisation hit also the urban centres of North-Eastern Slovakia. Many Evangelical pastors and public figures had to leave the region to exile and find asylum in Silesia or in Germany. ${ }^{2}$

The Reformation influenced the development of the music culture in towns in an appositive way. This was the case in both the major centres of musical life (Pressburg/ Bratislava, Košice) as well as in other free royal towns (Trnava, Trenčín, Skalica, Zvolen, Levoča, Kežmarok, Bardejov, Prešov, Sabinov a Krupina) and in the mining towns (Kremnica, Banská Štiavnica, Banská Bystrica, Banská Belá, Nová Baňa, Pukanec a Lubietová). The regions of Spiš, Šariš and eastern Abov were not directly hit by Turkish attacks thus music life in the towns enjoyed better conditions. Renaissance and later Baroque polyphonic and polychoral music was cultivated in the parish churches at a considerably high level. ${ }^{3}$ The existence of Lutheran municipal cantorates is well documented in the region of Spiš/Zips: from mid-16th century on Levoča and from the beginning of the 17th

1 KOVÁČ, Dušan. Dejiny Slovenska (= Dejiny štátov) [The Short History of Slovakia (= The History of the States)]. Praha: Nakladatelství Lidové noviny, 1998, pp. 65-74. Krátke dejiny Slovenska [The Short History of Slovakia]. Elena Mannová (ed.). Bratislava: AEP, Historický ústav SAV, 2003, p. 111. EVANS, Robert J. W. Vznik habsburské monarchie 1550-1700 [The Making of the Habsburg Monarchy 1550-1700]. Translation: Lenka Kolářová. Praha: Argo 2003, p. 15.

2 Evanjelická encyklopédia Slovenska [The Lutheran Encyclopaedia of Slovakia]. Borislav Petrík - Peter Rybár (eds.). Bratislava: BoPo, GBÚ ECAV, 2001, pp. 428-429. KOWALSKÁ, Eva. Na d’alekých cestách, v cudzích krajinách: sociálny, kultúrny a politický rozmer konfesionálneho exilu z Uhorska v 17. storoči [On Long Journeys, in Foreign Countries: the Social, Cultural and Political Dimension of the 17th Century Confessional Exile from the Historical Hungarian Kingdom]. Bratislava: VEDA vydavatel'stvo SAV, 2014, pp. 13-23.

3 RYBARIČ, Richard. Dejiny hudobnej kultúry na Slovensku I, Stredovek, renesancia, barok [The History of Musical Culture in Slovakia I, Middle Ages, Renaissance, Baroque]. Bratislava: OPUS, 1984. KAČIC, Ladislav: Od stredoveku po renesanciu. Barok [From the Middle Ages to the Renaissance. Baroque]. In Dejiny slovenskej hudby od najstaršich čias po súčasnost' [The History of Slovak Music from the ancient times to the present]. Oskár Elschek (ed.). Bratislava: Ústav hudobnej vedy SAV, ASCO Art et Science, 1996, pp. 54-138. 
century in other minor towns of the county like Lubica, Spišská Belá, Spišská Sobota, Poprad, Matejovce, Spišské Vlachy, Spišské Podhradie, Spišská Nová Ves and Smolník. ${ }^{4}$ The music repertoire of these Lutheran cantorates of that period is well documented in two musical collections: Levoča/Leutschau Lutheran Musical Collection (SK-Le) a Bardejov/ Bartfeld Lutheran Musical Collection (H-Bn $)^{5}$. One can follow the details of the musical life not only from musical sources but also from different types of archival sources: parish registers (birth-registers, obituaries, wedding-registers), registers of new burghers, account books, memorial books and personal correspondence. All these documents provide precious information for further research of the musical life: names and work descriptions of musicians and manufacturers of musical instruments, their migrations and personal histories, a typology of musical professions, the existence of musical institutions, the social status of municipal musicians (cantors, organists, trumpeters) and other personalities as pastors, rectors and donors or supporters of musical culture. ${ }^{6}$

\section{Transmission of musical culture}

The development of musical life in the towns of North-Eastern Slovakia was supported by the newly established reformist schools that introduced quality musical education. A key role in this process is to be attributed to the Lutheran theologian and school rector in Bardejov (the region of Šariš) Leonard Stöckel (1510-1560). Leonard Stöckel had studied in Wittenberg and was a close friend of Philipp Melanchthon. He started his professional career in Bardejov as a cantor and conductor of the choir of St. Egidius'. In 1540, he elaborated a set of principles titled Leges scholae Bartfensis with the aim to reform the municipal school. These rules were subsequently applied by him also in his own school management practice. Leonard Stöckel's texts of music have been preserved in the region of Spiš, in a composite volume shelfmark N 139 (olim S 38956), containing 21 handwritten and printed units (Lyceum Library in Kežmarok). ${ }^{7}$

4 PETÓCZOVÁ, Janka. Hudba ako kultúrny fenomén v dejinách Spiřa. Raný novovek [Music as a Cultural Phenomenon in the History of Zips. The Early Modern Period]. Bratislava: Ústav hudobnej vedy SAV, Prešovský hudobný spolok Súzvuk, 2014, pp. 53-96.

5 HULKOVÁ, Marta. Von der Forschung der Musikgeschichte in der Slowakei. Orgel-Tabulaturbucher der Musikaliensammlungen von Levoča (17. Jahr.). Musaica 18. Bratislava: SPN, 1987, pp. 57-79. HULKOVÁ, Marta. Rukopisné hlasové zošity Levočskej zbierky hudobnín (17. storočie) [The Handwritten Part-books of the Levoča Musical Collection (the 17th Century)]. Slovenská hudba 21, 1995, no. 2, pp. 203-227. HULKOVÁ, Marta. Musikalische Handschriften aus der Wendezeit des 16. und 17. Jahrhunderts in der Musikaliensammlung von Levoča (Leutschau/Lőcse). In The Musical Heritage of the Jagiellonian Era. Paweł Gancarczyk - Agnieszka Leszczyńska (eds). Warszawa: Instytut Sztuki PAN, Uniwersytet Warszawski, Biblioteka Narodowa, 2012, pp. 253-267. MURÁNYI, Róbert Árpád. Thematisches Verzeichnis der Musiksammlung von Bartfeld (Bártfa) (= Deutsche Musik im Osten 2) Bonn: Gudrun Schröder Verlag, 1991.

6 SZÓRÁDOVÁ, Eva. Všeobecnohistorické pramene v hudobnej historiografii [Allgemeinhistorische Quellen in die Musikhistoriographie]. In Ad honorem Richard Rybarič. Janka Petőczová (ed.) Bratislava: Ústav hudobnej vedy SAV, 2011, pp.134-141.

7 MATÚŠ, František. De Musica Leonardi Stöckelii. Slovenská hudba 17, 1991, no. 4, pp. 360-416. MATÚŠ, 
The composite volume includes unique manuscripts of Stöckel: a textbook on mathematics called Arithmetica, two textbooks on music - De musica I and De musica II, as well as Nicolaus Listenius's textbook De Musica | A Johanne Maioris Exposita. All these works were copied in 1567 by Johannes Fabri, rector of the school in Spišská Belá. Stöckel was evidently familiar with treatises on musical theory published in the 16th century. In the concept of his De Musica textbooks, he drew on the German Lutheran theoreticians Nicolaus Listenius and Heinrich Faber. Listenius studied in Wittenberg almost at the same time as Stöckel; that is why Stöckel was not only familiar with Listenius's first two textbooks Rudimenta musicae (Wittenberg 1533) and Musica (Wittenberg 1537); he knew their author personally.

The transmission of the ideas of the Reformation was a natural process - mediated by students, booksellers, tradesmen, any by the migration of clergymen and teachers. One of the main hubs of musical interaction was Wrocław/Breslau, a wealthy town in Lower Silesia, where Lutheran divine services took place in Saint Mary Magdalene's Church as early as in 1523. Nysa/Neisse, Opole/Oppeln and Zgorzelec/Görlitz were also famous Lutheran centres. ${ }^{8}$ As documented on the first page of the Kežmarok volume "Conscriptus Görlicij Anno 1566", the rector of the school in Spišská Belá, Johannes Fabri, lived in Zgorzelec in 1566. It was at that time, when a school in Zgorzelec was transformed into a Lutheran Gymnasium Augusteum and became famous partly because of its high standards in teaching and cultivating music. Johannes Fabri brought with him to Spiš two prints by Petrus Vincentius, the rector of the school in Zgorzelec. These books became part of the composite volume of Kežmarok - D. Erasmi Roterodami De Civilitate Morvm pverilium libellus and Inicia Doctrinae Arithmeticae olim a Glareano Tradita (1566). In Zgorzelec, Fabri also copied Listenius's textbook of music.

The transmission of musical culture took place within the territory belonging that time in its entirety to the reign of the Habsburg dynasty. The principal destination of the peregrinations was Wrocław - at that time a town several times larger than all the three major Upper Hungarian municipal centres - the free royal towns of Levoča, Prešov and Bardejov. Levoča, in mid 17th century counting some 4000 inhabitants, could be compared with the Silesian town of Brzeg/Brieg, while Wrocław was much larger (ca 40 thousand around the year 1675). The Wroclaw Lutheran Community had at its disposal three principal churches and seven further affiliated branches. Both Levoča and Bardejov Lutheran Community had at their disposal one principal church serving the Germanspeaking community and one minor church for Slovak-speaking worshippers. A specific multiethnic environment could be found in Prešov with three Lutheran Communities:

František. Príspevok k poznaniu vývinu hudobnoteoretického myslenia na Spiši v 16. storočí [A Contribution to the Knowledge of the Development of Music Theoretical Thinking in Spiš in the $16^{\text {th }}$ Century]. Musicologica Slovaca et Europaea 19, 1994, pp. 35-40. PETÖCZOVÁ, Janka. Leonard Stöckel a hudba [Leonard Stöckel and Music]. In Leonard Stöckel a reformácia v strednej Európe (= Acta Collegii Evangelici Prešoviensis XI). Peter Kónya (ed.). Prešov: Publishing House of the University of Prešov, 2011, pp. 70-84.

8 JEŻ, Tomasz. Łacińska twórczość muzyczna w ewangelickim Wrocławiu. Problem trwałości tradycji w czasach przemian konfesyjnych, Barok 2004, No 2, pp. clxxxv- clxxxviii. PRZYBYSZEWSKA - JARMIŃSKA, Barbara. BAROK, czéśc pierwsza, 1595-1696 (= Historia Muzyki Polskiej III) Stefan Sutkowski (ed.). Warszawa: Sutkowski Edition, 2006, pp. 116, 189. 
a German-speaking, a Slovak-speaking and a Hungarian-speaking one. The Lutheran cantorates in the towns of North-Eastern Slovakia were established under direct influence of cantorates in Central Germany and in Silesia. Chronologically, the first evidence of regular payments to singers of the municipal Lutheran cantorate in Levoča are documented from mid-16th century (Dem Cantory sein tysch, Schulmeister, Astanten). Later, the names are documented as well; cantors: Valentin Miska in Levoča 1580 - 1600, Zacharias Wier from Berlin in Kežmarok since 1596, Joachim Leibitzer in Spišské Vlachy since 1592, Georg Bartholomaeus in Spišská Nová Ves, cantor Caspar Stein in Levoča etc. From the mid-17th century, music of domestic composers has been preserved, as well: of Thomas Gosler, an exulant from Flensburg, notary in Kežmarok 1625-ca 1646; of Samuel Marckfelner, an organist in Levoča 1648-1674, of Georg Wirsinger, a school rector in Spišská Nová Ves, 1625-1628; or of Johann Schimrack sen., organist in Spišské Podhradie 1630-1657.

Details of the musical life are documented since the beginning of the 17th century. A list of musical instruments in charge of the municipal trumpeter, dated 1635, has been preserved in the Memorial book deposited in the municipal archive of Spišská Nová Ves. ${ }^{9}$ The testament of Anna Feüchter, the widow of a well-off Mayor of Spišská Nová Ves has been preserved in Municipal Judicial Book (1622); this testament contains information about donating part of her property to the Fraternitas Litteratorum. The widow bequeathed her property to the town's parish pastors (German and Slovak) as well as the Löbliche Fraternitet Literator[um] of which her son Peter Feüchter was an active member. ${ }^{10}$ Here, the literary fraternity preserved its urban character as well as its system of guild organisation longer into the 17th century, than it was the case elsewhere in Europe. In Spiš, Fraternitas litteratorum combined thorough German music tradition of Lutheran cantorates with multi-ethnic Slovak-German environment. Beside of that, a municipal musical society Collegium Musicum existed in Spišská Nová Ves. ${ }^{11}$

There are lot of references to musical contacts and interactions of students, teachers, musicians and priests with Silesian subjects. ${ }^{12}$ The records document to purchases of books and songbooks in Silesian towns or, on the other hand, to activities of Silesian rectors and cantors in urban communities of the North-Eastern Slovakia: 1601: "Inventarium Benedicti Johans Verlassenschaft: ... Compendien Gorlitzer 8, ... Gesangbücher 38, Ein gesangbuch in octavo ... Ein bündel Bücher soll man von Preslau pringen"; 1608: "2.Sept. schickt man durch H. Paul Altmann den Caspar Klosz nach Breszlaw, so er H. Magistro Praetorio geliehen, fl. 9 den. 72"; 1608 (rector): „Leonhard Martini aus Bielitz”; 1625: „Den ... Orgelmacher aus Pohln dem Orgelmacher aus dem Schlesien gegeben: auf Kost dann auff Correctur der Orgel fl. 80, zusammen

9 Štátny archív v Košiciach (ŠA-K), Archív Spišská Nová Ves (A-SNV). Pamätná kniha mesta [Memorial book], shelfmark 2 - K/I, 1634-1738, sine p.

10 ŠA-K, A-SNV, Kniha mestského súdnictva [Municipal Judicial Book], shelfmark 86 - K/I, 1594-1633, sine p.

11 FRÖHLICH, David. Medulla geographiae practicae. Bartfeld 1639, p. 352.

12 PETŐCZOVÁ, Janka. The Role of Silesia in the Development of Musical Culture in the Towns of Spiš/ Zips and Šariš/Scharosch. In The Musical Culture of Silesia before 1742. New Contexts - New Perspectives (= Eastern European Studies in Musicology 1, M. Gołąb, ed.). Paweł Gancarczyk - Lenka Hlávková-Mráčková - Remigiusz Pośpiech (eds.). Frankfurt am Main: Peter Lang GmbH, 2013, pp. 161-178. 
fl. 168 den. 16"; ${ }^{13}$ 1629: "Georg. Tranoscius Diener der Vinsch allss auss Mehren, vndt ...auss Ober Schlesien Exil” [5th October 1629]; ${ }^{14}$ 1634: "Adamus Gdacius Cruciburg, p. t. Scholae Varal. Cantor"; 1635: “Thomas Meritovinus Siles. Cant. Cibinien”; ${ }^{15}$ 1646-1648: "Daniel Fabri aus Schlesien"; ${ }^{16}$ [Levoča]: 1647: "Eodem dato [October] sind auch Schreiben von Hans Wolff [HandelszMann] von Breszlau ankommen wegen vnsers Herrn Pfarrers.", "Eodem [2 November] ist vnser neüer Herr Pfarrer Herr Doctor Christoph Schlegel [... gewesenen Pfarrer in der Neüstad zu Breszlau], mit sambt den Neüen Herrn Rector Georg Krischke, vnd ihren mitgeferthen, Gott lob und danck, nebens vnsern Herrn Frisch und gesund allhier ankommen, ...", 1655: "20 dito [Septembris] Ist die Fraw Pfarrin mit allen Kindern nach Breszlau gezogen H. Pfarrer aber hatt sich ausz dem Pfarrhoff wegk, in desz Magister Zablersz behausung begeben. ". ${ }^{17}$

\section{Musical sources and musical personalities}

The musical manuscripts preserved in the part A of the Levoča/Leutschau Lutheran Musical Collection are also great sources of information of learning about musical contacts, musical repertory and the music of domestic composers. The most important among them are six tablature-books SK-Le, MUS A 1- MUS A 6 and one partiture-book SK-Le, MUS A 74: 1) tablature-book shelfmark MUS A 1 (olim 13990a), the so-called Caspar Plotz Tablature, created by one copy writer (attributed to Caspar Plotz); 2) tabulaturebook shelfmark MUS A 2 (olim 13990b), the so-called Johann Plotz Tablature, created by three copy writers; this tablature was formerly called The Second Tablature of Caspar Plotz, because the first 31 works have been written by the same copyist as in the tablature MUS A $1 ;^{18}$ new affiliation was created in 1985 after identification of the manuscript of Johann Plotz as a one of the three copyist; ${ }^{19}$ 3) tabulature-book shelfmark MUS A 3 (olim 13992), the so-called Johann Schimrack sen. Tablature II.); 4) tabulature-book shelf-

13 LIPTÁK, Johann. Geschichte des evangelischen Distriktual-Lyzeums A. B. in Kesmark. Kežmarok-Kesmark: Herausgegeben im Selbstverlage des Lyzealpatronates anläßlich der 400-Jahrfeier des Lyzeums, 1933, pp. 25-28, $42,49$.

14 PETÓCZOVÁ, Janka. Slovenský prvok v hudobnom živote Levoče v 17. storočí [The Slovak Element in the 17th Century Musical Life of Levoča/Leutschau]. Musicologica Slovaca et Europaea 19, 1994, p. 73.

15 ČAPLOVIČ, Ján. Bibliografia tlači vydaných na Slovensku do roku 1700, [The Bibliography of the Prints in Slovakia until 1700], vol. 1. Martin: Matica slovenská, 1972, pp. 303, 305-306.

16 LIPTÁK, Johann. Geschichte des evangelischen Distriktual-Lyzeums A. B. Ref. 13, p. 42.

17 BAL, Jeromos - FÖRSTER, Jenő - KAUFFMANN, Aurél. Hain Gáspár Lócsei Krónikája. Lőcse: Reiss Józs. T. Könyvnyomó Intézete, 1910-1913, pp. 234-235, 263.

18 BURLAS, Ladislav - FIŠER, Ján - HOŘEJŠ, Antonín. Hudba na Slovensku v 17. storoč [The Music in Slovakia in the 17th Century]. Bratislava: Vydavatel'stvo SAV, 1954, pp. 99-103.

19 Johann Plotz was identified as one of the three writers of the Tabulature-book MUS A 2 (f. 159v-179r) by comparison with the signature of Johann Plotz in the printed book of Johann Vogel Psalmen Davids (Nuremberg 1638), which is located in the Historical Library of the Congregation of the Evangelical Church of the Augsburg Confession in Levoča (shelfmark 369). HULKOVÁ, Marta. Levočská zbierka hudobnín [Levoča Musical Collection], vol. I. Diss. Bratislava: FFUK, 1985, pp. 47-48. Copy of the manuscript see: HULKOVÁ, Marta. Levočská zbierka hudobnín, vol. II, pp. 326-327. 
mark MUS A 4 (olim 13993), the so-called Johann Schimrack sen. Tablature I.; the two of them - the tablatures MUS A 3 and MUS A 4 were formerly incorrectly called Johann Schimbracký (Schimbraczky) Tablatures $;{ }^{20}$ new affiliation was created after $2004,{ }^{21}$ by correct identification of the family name of the composer Johann Schimrack sen. (?-1657); ${ }^{22}$ 5) tabulature-book shelfmark MUS A 5 (olim 13994, the so-called Samuel Marckfelner Tablature II.); this tablature was formerly called The Anonym Tablature II; ${ }^{23}$ new affiliation was created in 1981, after identification of the manuscript of Samuel Marckfelner as one of the copyist; ${ }^{24}$ 6) tabulature-book shelfmark MUS A 6 (olim 13991, the so-called Samuel Marckfelner Tablature I.); 7) partiture-book shelfmark MUS A 74 (sine olim shelfmark); the copyist of the source is unknown; there are two records inside: "Tobias Haigerius I Cruciburgô Silesius" on the title-page and "Jacob Luschmann ... 1647" on the folio 90r. The personality of Tobias Haigerius is unknown. According to the annals of Caspar Hain, Jacob Luschmann was a member of Levoča's municipal council in 1648: "Volgen die H. H. Vormündt, sambt der gantzen Löblichen Gemein: ... H. Jacob Luschmann. Leinweber.” ${ }^{25}$

\section{The Plotz family}

Few information has been preserved as far as the identity of the writers of Plotz Tablatures. The copyist of the first tablature (MUS A 1) is evident from the title page: "Caspar Plotz | 1603". This is the oldest record about any Plotz family member in Spiš. In earlier literature Caspar Plotz used to be mentioned hypothetically as organist in Levoča, in relationship with Johann Plotz (?-1680), who served as organist here in the period of 1641-1648. Beside of him, Georg Plotz (?-1661) served as an organist in Kežmarok in the years of 1639-1649, and later, in the period of 1650-1661 he became the organist of the parish German church in Prešov/Eperies (region of Šariš). This fact provoked a hypothesis that Johann and Georg might have been brothers, since Johann worked in

20 BURLAS, Ladislav - FIŠER, Ján - HOŘEJŠ, Antonín. Ref. 18, pp. 108-119. HULKOVÁ, Marta. Von der Forschung der Musikgeschichte in der Slowakei. Ref. 5.

21 PETŐCZOVÁ-MATÚŠOVÁ, Janka (Ed.). Johann Schimrack / Ján Šimrák: Lobe den Herren, meine Seele! / Chvál, duša moja, Hospodina! [1642] (= Musica Scepusii Veteris II/1). Prešov: Prešovský hudobný spolok Súzvuk, 2004.

22 In musicological literature the family name of Johann Schimrack has long been written as 'Šimbracký'. This incorrect use of the composer's name comes from an incorrect reading of the genitive case of the word Schim(b)rackii; with Latin suffix -ii as Schimbrackii, Schimrackii and exchanging the genitive case to the nominative case. PETŐCZOVÁ, Janka. Šimrák versus Šimbracký. Mythen und Realität in der slowakischen Musikhistoriographie. Hudebni věda 52, no. 3-4, Praha 2015, pp. 273-316.

23 BURLAS, Ladislav - FIŠER, Ján - HOǨEJŠ, Antonín. Ref. 18, pp. 119-121. Dejiny slovenskej hudby. [The History of Slovak Music]. Bratislava: Vydavatelstvo SAV, 1957, pp. 106-107.

24 MATÚŠ, František (ed.). Tabulatúrny zbornik Samuela Marckfelnera. Výber (= Stará hudba na Slovensku/Alte Musik in der Slowakei 4). Bratislava: OPUS, 1981, pp. 7-9.

25 BAL, Jeromos - FÖRSTER, Jenő - KAUFFMANN, Aurél. Ref. 17, p. 228. PETŐCZOVÁ, Janka. Polychorická hudba v levočskom rukopisnom zborníku sign. 74 A. [Polychoral Music in the Levoča/Leutschau Musical Manuscript shelfmark MUS A 74]. Hudebni věda XXV, 1988, No. 3, p. 216. 
Levoča almost in parallel to Georg in Kežmarok. ${ }^{26}$ There is, however, no archival evidence in the sources of Slovak archives testifying to this hypothesis.

After 1989, the potential for widening the heuristic research increased, as well as the possibility of international cooperation. Based on this new research a new information related to the genealogical research of the Plotz family in Central Europe was disclosed. This is a possessor's entry "Johannes Plotz Vom Brieg | Caspar Plo(tz) organist | zu brieg in der PfarHer | Kirch", to be found in a musical collection of Polish proveniences deposited in the former Preußischen Staatsbibliothek Berlin, tablature-book shelfmark Ms. mus. 40056. This comes from the original musical collection in Wroclaw, currently deposited in Biblioteka Jagiellonska, Kraków PL-Kj). ${ }^{27}$ According to this entry Caspar Plotz was an organist in Brzeg (Brieg). The relationship between Johann and Caspar Plotz in Brzeg and the Plotz's living in Spiš and Šariš remain unclear. The Silesian origin of Johann Plotz seems to be quite certain, proved e.g. by the up to recently omitted abbreviation B.S. in his possessor's entry "Johannes Plotz. B. S. A[nno] 1645 Ad. 10. Sept: I In Leutsch p. T. Organista" to be found in Johann Vogel's song-book Psalmen Davids (1638)". ${ }^{28}$ The abbreviation „B. S.“ after the name we can read as Bregen Silesius. The Silesian origins of Johannes Plotz is not mentioned, however, by the (otherwise very consistent) annalist of Levoča Caspar Hain. He noticed the entrance of Johann Plotz to the function of organist in 1642 like this: "Die 16. Februarij Ist an statt Herrn Apelles Herr Christophorus Werner Misnicus Cantor worden, ond Herr Tobiasz Cruciger, an statt | Seiner Senior. So ist auch nach dem Johanni Pfadenhauer, Johannes Plotz worden." ${ }^{99}$ The account books register expenses to the favour of Johann Plotz for the first time in the first quarter of 1641: " $p 4$ Angaria dem Joh. Plotz Organista ... fl. 25 | It. dem Calcanten ... fl. 1". "Johann (Hansz) Plotz" received from the town 25 (later 26) guilders quarterly, and also other occasional incomes (e.g. on 16th October 1648 he received a contribution of 2 guilders for purchase of firewood). ${ }^{30}$ He received the last payment on 18th December 1648; the next sum of 7 guilders and 20 dinars was already paid to organist Samuel Marckfelner on 30th December 1648. ${ }^{31}$

26 MATÚŠ, František (ed.). Ref. 24, pp. 7-9. [MATÚŠ, František.] Plotz, Gašpar (16./17.); Plotz, Ján (ca 1620-1680); Plotz, Juraj (ca 1610 - ca 1660). In Slovenský biografický slovnik, vol. IV. Martin: Matica slovenská, 1990, p. 489. The Levoča account books from the era of Reformation disclose the names of the following organists of the parish church: Joseph Traininger 1590-1605; Johann Miska 1610-1630; Johann Pfadenhauer 1630-1641; Johann Plotz 1641-1648; Samuel Marckfelner 1648-1674.

27 Klaus-Peter Koch presumes, on the basis of his research of the tablature-book PL-Kj, shelfmark Ms. mus. 40056, that the Plotz's might be disciples of Samuel Scheidt. KOCH, Klaus-Peter. Das Claviertabulaturbuch von Caspar und Johannes Plotz. Bemerkungen zu Samuel Scheidt anhand der wieder aufgefundenen Handschrift Mus. ms. 40056 der ehemaligen Preußischen Staatsbibliothek Berlin. In Beiträge zur musikalischen Quellenforschung. Protokollband Nr. 2 der Kolloquien im Rahmen der Köstritzer Schütz-Tage 1988-1990. Bad Köstritz: Forschungs- und Gedenkstätte Heinrich-Schütz-Haus Bad Köstritz, 1991, pp. 229-243.

28 Ref. 19.

29 BAL, Jeromos - FÖRSTER, Jenő - KAUFFMANN, Aurél. Ref. 17, p. 199.

30 Štátny archív v Prešove (ŠA-P), Špecializované pracovisko Spišský archív v Levoči (SpA-L), Magistrát mesta Levoča (MML), Maculatorium pro Anno Domini 1641-1648, shelfmarks AML XXI A/59, p. 89 to AML XXI A/66, p. 93, shelfmark AML XXI A/66, p. 70.

31 SpA-L, MML, "Dem Neuen Organisten weg. seiner v[er]richtung auf der Orgel verehrt 7 fl., 20 [den]", shelfmark AML XXI A/66, p. 68. 

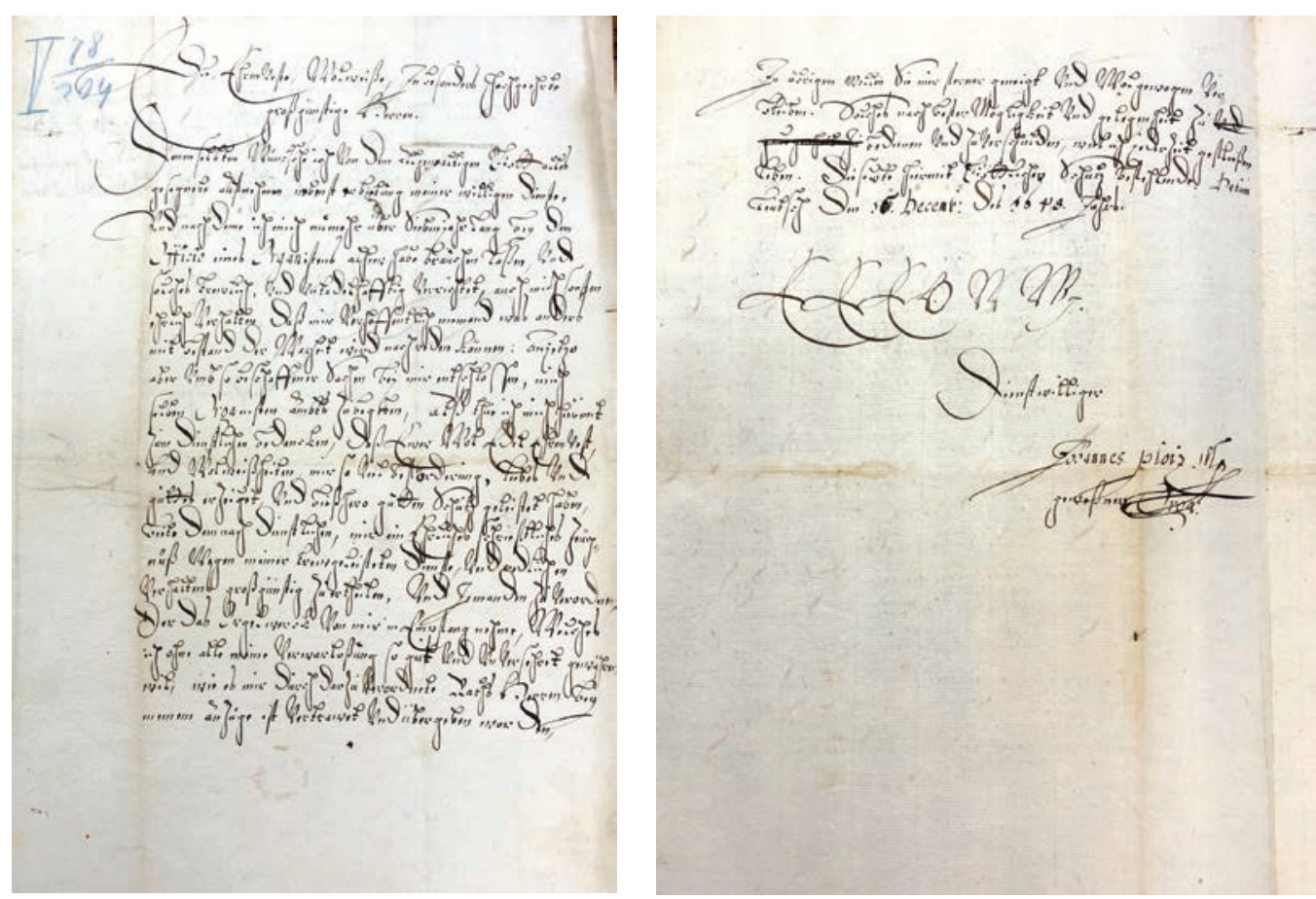

Fig. 1a, 1b Letter of Johann Plotz, 16th December 1648. Štátny archív v Prešove, Špecializované pracovisko Spišský archív v Levoči, Fond Magistrát mesta Levoča,

Correspondence, shelfmark V. 78/204.

Currently we have access to biographical data on and information about Johann Plotz's activities in Levoča from three sources: 1) municipal account books (1641-1648); 2) Caspar Hain's annals (1648, 1655); 3) such manuscript archival documents that have not been subject to research so far: two letters written to the municipal council of Levoča manu propria (14th December 1648, 16th December 1648, Fig. 1a, 1b), ${ }^{32}$ his signature as one of the witnesses in the testament of "Kattharina Wiesenbergerin gebohren Schwarzin" (1672, Fig. 2) (33 $^{33}$ and the copy of his own testament dated in 1680 (Fig. 3a, 3b, 3c, 3d). ${ }^{34}$

Both letters dated in 1648 were written by Plotz a fortnight before his departure from the post of the organist, in the days when a conflict between him and the municipal council broke out. In the letter he refers to his own rights anchored in the invitation letter (Vocation), according to which he was freed from paying taxes (Taxa). It seems that the situation turned as dramatic that it resulted in resignation of the organist from his

32 SpA-L, MML, Correspondence, shelfmark V. 78/203, 204.

33 The testament was written on 14th May 1672; Katharina Wiesenberger divided all his movable and immovable property between the Church, school staff and her relatives (Schwarz). The document was subsequently authenticated by three witnesses on 11th July 1672 "Caspar Hain / Juratus Assesor ibidem MP, Caspar Söldner / Stadtschreiber MP, Johann Plotz. MP”. SpA-L, MML, shelfmark XIX 17/28.

34 SpA-L, MML, Testaments, shelfmark XIX 169. 


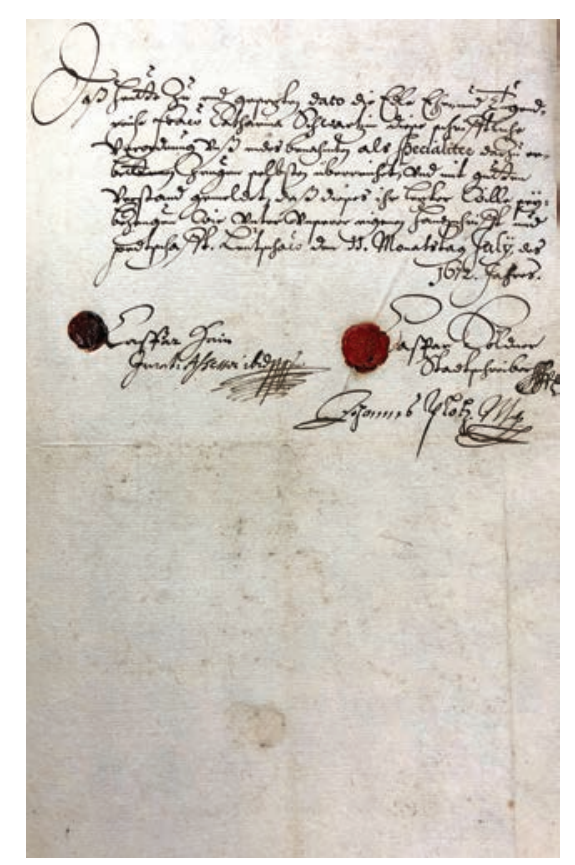

Fig. 2 Testament of Katharina Wiesenberger, the last page, 11st July 1672. Štátny archív v Prešove, Špecializované pracovisko Spišský archív v Levoči, Fond Magistrát mesta Levoča, Testaments, shelfmark XIX 17/28.

post. The council paid him his last salary at the end of the current month and immediately terminated his contract. The seriousness of the situation is documented by a rather lengthy entry devoted to the matter by the annalist Caspar Hain:

"16 Dito [Decembris 1648] Hatt der Organist Johann Plotz abgedanckt vnd Einem E. W. Rath den Stuhl vor die Thür gesetzt, vmb weilln mann Ihm auch eine Taxa aufferlegt hatt, darwieder der Herr Pfarrer geprediget, weill Ihm nun Ein E. W. Rath gestraffet, dasz Er zum Pfarrer klagen gangen, hatt der Pfarrer den Sontag darauff eine solche Predigt wieder die Obrigkeit, vnd den H. Richter ausz einen Zettel allesz ablesende wasz vorgangen, gethan, vnd so viell zuuerstehen geben, das die Obrigkeit nicht macht hätte, denen Kirchenbeamten zugebietten, sondern solches sein Thun wäre, vnd sein ambt, ohne dessen willen mann | nichtsz thun könte. Da doch die Obrigkeit vnschuldig gewesen vnd Itme des dienstes, wie Ers begehret hatt, erlassen, darumb dann weill solche sachen nicht auff die Cantzel gehöreten ein grosser vnrath entstanden, die Herrn vorMünd mit der Gemeine zusamen gangen, vnd dem Herr Pfarrer solches vorgehalten; welcher sich aber entschuldiget, dasz Er hiemit nichts vnrechtesz gethan hätte, damit war aber ein E. W. Rath nicht zufrieden, haben es jedoch weill die feyertage nahe waren hiemit auff diesesmahl bewenden lassen. Nach verbrachten feyertagen aber ist die Gemain nebensz einem auszschusz der schwartzen Gemain wieder zusamen kommen, und begehret, dasz mann den Organisten bisz zu ausztrag der sachen als den vrsächer an solchen händeln in die Bitteley führen soll, welchesz auch geschehen, von Herrn Pfarrer aber ist begehret worden, das Er offentlich selbst wiederruffen, vnd einen 


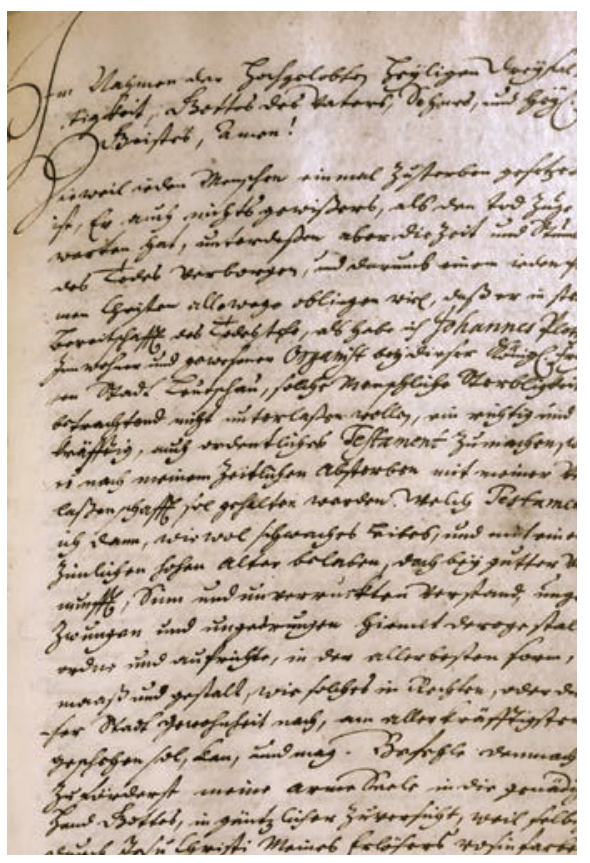

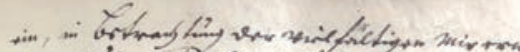

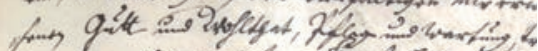

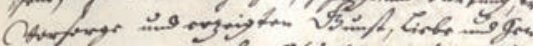

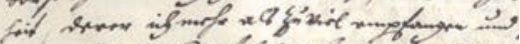

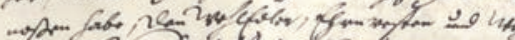

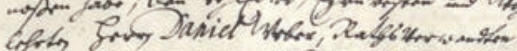

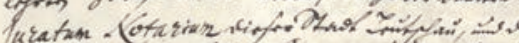

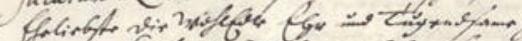

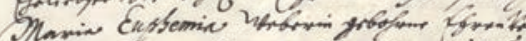

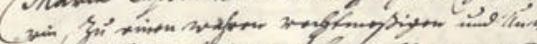
ervorflezan thivernal fris a Clen m.nin?

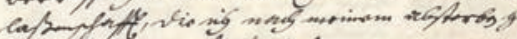

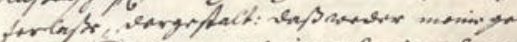

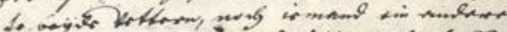

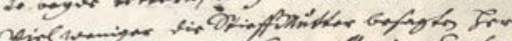
Prand vater in osuse Maria Esrbem

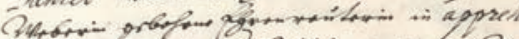

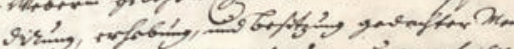

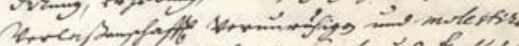

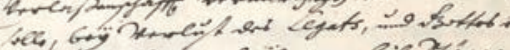

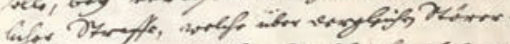

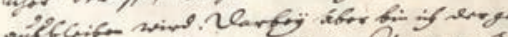

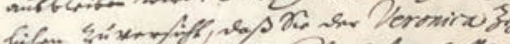

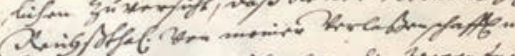

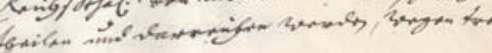
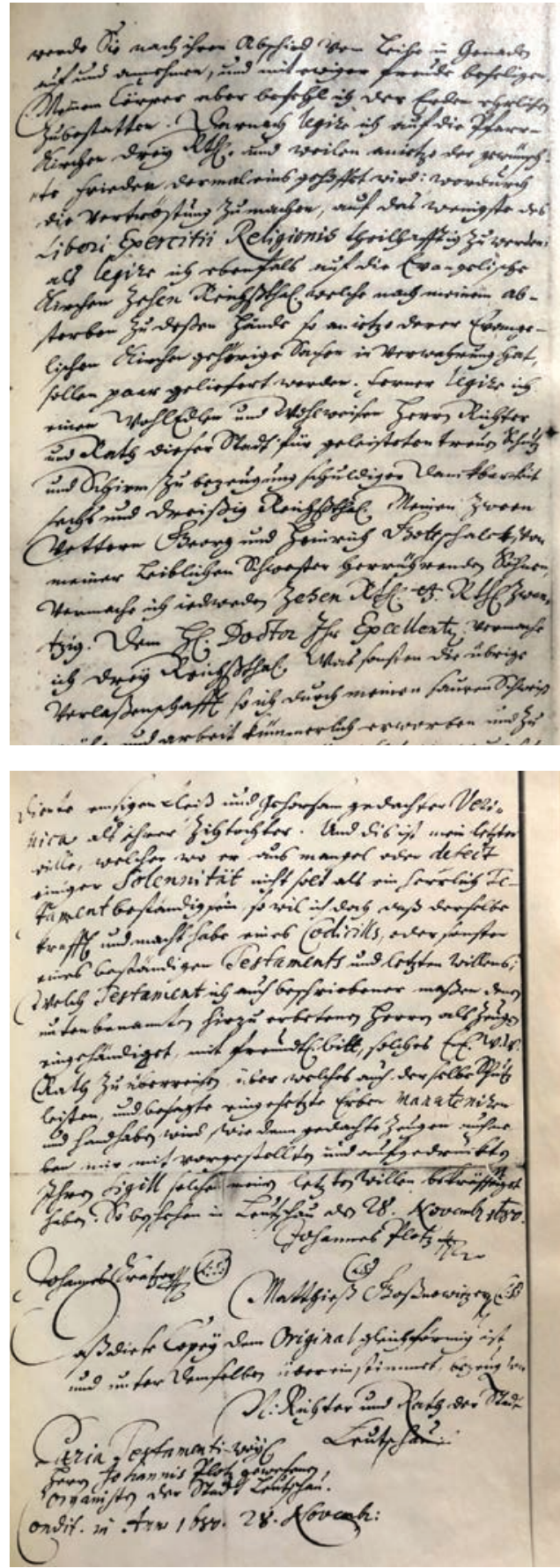

Fig. 3a, 3b, 3c, 3d Copy of the testament of Johann Plotz, 28th November 1680. Štátny archív v Prešove, Špecializované pracovisko Spišský archív v Levoči, Fond Magistrát mesta Levoča, Testaments, shelfmark XIX 169. 
Abtreg von der Cantzel thun solt, welches Er durch ausz nicht thun wollen, sondern esz ehe vor Geistlich vnd weltlich Recht kommen laszen wollen. damit nun die Sach sich nicht ferner verzögere, vnd was anders daraus entstünde, Ist Ihme den 28 Decembris angedeütet worden: Er sole sich hinführo in acht nehmen, vnd nicht weiter greiffen dann Ihm gebühret, dann ein Obrigkeit Ihr Ius Patronatus Ihme nicht nehmen lassen will, | hab Er wasz zustraffen, soll Er es thun, wie es sich gebühret, wo nicht so soll Er sehen, das Ihme nicht ein andermahl ein spott wiederfahre. Ist also den 29 Decembris Herr Samuel Marckfeldner von Wallndorff, welcher ohngefehr anhero kommen, zu einen Organisten angenommen worden." 35

Nevertheless, Johann Plotz did not quit Levoča in 1648. He continued to live in the town for the next 32 years. This is testified by a short notice in Caspar Hain's annals dated 17th April 1656, according to which "der Organist Johann Plotz" was a troublemaker who was arrested by the municipal council for causing public nuisance. ${ }^{36}$ The last evidence about Johann Plotz's presence in Levoča can be found in his testament from 28th November 1680. This is the year of his decease. ${ }^{37}$

"Im Nahmen der Hochgelobten Heÿligen Drë̈faltigkeit, Gottes des Vaters, Sohnes, und Heÿl. Geistes, Amen!

Dieweil ieden Menschen einmal zu sterben gesetzet ist, Er auch nichts gewiszers, als den tod Zugewarten hat, unterdeßen aber die Zeit und Stunde des Todes verborgen, und darumb einem ieden frommen Christen allewege obliegen wiel, daß er in steter Bereitschafft des Todes stehe, als habe ich Johannes Plotz Innwohner und gewesener Organist bey dieser Königl. Frë̈en Stadt Leutschau, solche Menschliche Strebligkeit betrachtend nicht unterlaßen wollen, ein richtig und kräfftig, auch redentliches Testament zumachen, wie es nach meinem Zeitlichen Absterben mit meiner | Verlaßenschafft sol gehalten werden. Welch Testament ich dann, wiewohl schwaches Leibes, und mit meinem Zimlichen hohen Alter beladen, doch bë̈ gutter Vernunfft, Sinn und unverruckten Verstand, ungezwungen und ungedrungen hiemit derogestalt ordne und aufrichte, in der allerbesten form, maaß und gestalt, wie solches in Rechten, oder dieser Stadt gewohnheit nach, am allerkräfftigsten geschehen sol, kan, und mag. Befehle demnach zuförderst meine arme Seele in die gnädige Hand Gottes, in gantzlicher Zuversicht, weil selbige durch Jesu Christi Meines Erlösers rosinfarbes Blutt von Sünden rein abgewaschen worden, Gott | werde Sie nach ihren Abschied vom Leibe in Genaden auf und annehmen, und mit ewiger freude beseligen. Meinen Cörper aber befehle ich der Erden ehrlichen zu bestatten. Darnach legiere ich auf die Pfarr-Kirchen drë̈ Rtlf. und weilen anietzo der gewünschte Frieden dermaleins gehoffet wird: wordurch die Vertröstung zu machen, auf das wenigste des Liberi Exercitii Religionis theilhafftig zu werden, als legiere ich ebenfals auf die Evangelische Kirchen Zehen Reichßthal. welche nach meinem abstreben zu deßen Hände so anietzo derer Evangelischen Kirchen gehörige Sachen in Verwahrung hat, sollen paar geliefert

35 According to Caspar Hain's Annals the organist submitted his own resignation, because of the taxes levied upon him. He was backed by the pastor in his Sunday sermon, when he sharply criticized the municipal council for this step. The council reprimanded the pastor, however, because of the Advent, they kept truce. The conflict between the church and the council lasted two more weeks, being ended by firing the organist by the council. BAL, Jeromos - FÖRSTER, Jenő - KAUFFMANN, Aurél. Ref. 17, pp. 238-239.

36 BAL, Jeromos - FÖRSTER, Jenő - KAUFFMANN, Aurél. Ref. 17, p. 265.

37 The exact date of Johann Plotz's death cannot be proved, because the page listing the entries for the year 1680 in the Evangelical obituary is missing. In the next year of 1681, however, Johann Plotz is not shown among deceased. SA-P, SpA-L, Collection of Parish Registers, Evangelical obituary 1680, 1681. 
werden. Ferner legire ich einen WohlEdlen und Wohlweisen Herrn Richter und Rath dieser Stadt für geleisteten treuen Schutz und Schirm zu bezeugnung schuldigen Dankbarkeit sechs und dreißig Reichßthal. Meinen Zween Vettern Georg und Heinrich Gottschalck, von meiner Leiblichen Schwester herrührenden Söhnen, Vermache ich iedweden Zehen Rthl. etz. Rthl. Zwantzig Dem H. Doctor Ihr Excelentz vermache ich Drey Reichßthal. Was sonsten die übrige Verlaßenschafft so ich durch meinen sauren Schweiß mühe und arbeit kümmerlich erworben und zu wegen gebracht, betriefft, instituire ich und setze | ein, in Betrachtung der vielfältigen mir erwiesenen Gutt und Wohlthat, Pflege und Wartung, treuen Versorge und erzeigten Gunst, Liebe und Gewogenheit, derer ich mehr als zu viel empfangen und genoßen habe, den WohlEdlen, Ehrenvesten und wohlgelehrten Herrn Daniel Weber, Ratus Verwandten und Juratum Notarium dieser Stadt Leutschau, und deßen Eheliebste die WohlEdle Ehr und Tugendsame Frau Maria Euphemia Weberin gebohrne EhrenRueterin, zu einen wahren rechtmeßigen und Unwiederrufflichen Universal Erben aller meiner Varlaßenschafft, die ich nach meinem absterben hinterlaße, dergestalt: daß weder meine gedachte beÿde Vettern, noch iemand ein anderer viel weniger die StieffMutter besagten Herren Danieli Weber und Frau Maria Euphemia Weberin gebohrene Ehrenreuterin in apprehendirung, erhebung, und Besitzung gedachter Meiner Verlaßenschafft verunruhigen und molestiren sole, beÿ Verlust des Legats, und Gottes sonstlicher Straffe, welche über dergleichen Störer nicht ausbleiben wird. Darbeÿ aber bin ich der gäntzlichen Zuversicht, daß Sie die Veronica Zehen Reichßthal. von meiner Verlaßenschafft mittheilen und darreichen werden, wegen treuer | Dienste emsigen Fleiß und Gehorsam gedachter Veronica als ihrer Zihtochter. Und dies ist mein letzter Wille, welcher wo er aus mangel oder defect einiger Solennität nicht solt als ein herrlich Testament geständig sein, so wil ich doch daß derselbe krafft und macht habe eines Codicills, oder sonsten eines beständigen Testaments und letzten Willens; Welch Testament ich auch beschriebener maßen denen untenbeamten hierzu erbetenen Herren als Zeugen eingehändiget, mit freundtl. bitt, solches E. E. W. W. Rath zu überreichen, über welches auch der selbe Schutz leisten, und besagte eingesetzte Erben maauteniren und handhaben wird, wie denn gedachte Zeugen auch neben mir mit vorgestellten und aufgedrückten Ihren Sigill solche meinen letzten Willen bekräfftiget haben. So beschehen in Leutschau den 28. November 1680.

Johannes Plotz m.p. /L. S./

Johannes Kratzer /L. S./

Matthias Gosnowitzer /L. S./

Daß diese Copë̈ dem Original gleichförmig ist und unter demselben übereinstimmet, bezeugen w.

N: Richter und Rath der Stadt Leutschau

Paria Testamenti wë̈l.

Herrn Johannis Plotz gewesenen

Organisten der Stadt Leutschau.

Condit. in Anno 1680. 28. Novembr:"

We can learn from the testament that Johann Plotz had no wife or children that time. From siblings alive he mentions only his sister. We do not know his possible family relationship to the organist Georg Plotz, who died in Prešov in 1961. Moreover, the testament does not include any information about the estates of Johann Plotz, about his books, scores or musical instruments. Nothing of the musical works of Georg Plotz has been preserved, either, though we know positively that he certainly composed music. After 
his death in Prešov the notary produced an inventory of musicalia of the parish German church Catalogus Partium seu Librorum Musicorum ad Templum Eperjen[se] Parochiale (25th July 1661), part of which is also an inventory of musical pieces of Georg Plotz's estate - "Ex Legatione p[er] m[anus] Domini Georgii Plotschii". This included manuscript copies of works by Johann Kusser, Alessandro Grandi and Johann Rovetta, prints of Johann Rosenmüller and Andreas Hammerschmidt, as well as three out of the four volumes of Geistlichen Concerten und Harmonien edited by Ambrosius Profius. Also are listed "Collectanea et Manu-Scripta Georgii Plotschii (NB. absque Basso Gen: ... l[ibri] 16)" and in the common part of the church's property other works of Georg Plotz are listed, most propably prints: "Georgii Plotzchii Erster Theil des Geistliche[en] Musicalisch[en] Triebs ... l[ibri] 5.88

\section{Musical repertory}

Despite the richness of archival information on musical life in many urban communities of North-Eastern Slovakia, Levoča and Bardejov take the lead. Bardejov occupies an outstanding position because of the Lutheran Musical Collection, now deposited in Budapest; and Levoča because of the Lutheran Musical Collection preserved in situ. The Levoča Lutheran Musical Collection contains a common musical repertory of the European protestant area, including some unique pieces by lesser-known composers, in that number also musicians active in Spiš. Polyphonic and polychoral music can be found in prints, handwritten tablature-books and part-books. As many as 100 cori spezzati works by Gregor Lange, Jacob Regnart, Hans Leo Hassler, Jacob Handl-Gallus, Giovanni Pierluigi da Palestrina, Andrea and Giovanni Gabrieli from his Sacrae symphoniae 1597 (etc.) can be found in tablature books of Caspar and Johann Plotz from the turn of 17th century (MUS A 1, MUS A 2 olim 13990a, 13990b). The oldest prints containing early Baroque polyphony by German composers have been preserved in the Levoća Lutheran Musical Collection dated 1602-1620; they include Magnificat octo vocum and Cantiones sacrae of Hieronymus Praetorius, the Psalmen Davids (SWV 22-47) of Heinrich Schütz, etc.

The print of Heinrich Schütz's Psalmen Davids (1619) includes manuscript appendices with polychoral works of European and domestic composers: Giovanni Gabrieli, Asprilio Pacelli, Luca Marenzio, Matthäus Apelles von Löwenstern and Johann Schimrack senior (Ján Šimrák starši in Slovak language transcription). This organist of the German Lutheran Church in Spišské Podhradie (from 1630 to 1657) is actually one of the best-known composers of the first half of the 17th century active within the territory of NorthEastern Slovakia; together with Zachariáš Zarevúcky (Zacharias Zarevutius, 1605-1667), an organist in Bardejov, as well as Thomas Gosler, and Georg Wirsinger. The unique

38 PETŐCZOVÁ, Janka. Katalóg hudobnín farského kostola v Prešove z roku 1661 [Katalog der Musikalien der Pfarrkirche in Prešov aus dem Jahre 1661]. In KALINAYOVÁ, Jana et al. Hudobné inventáre na Slovensku zo 16. a 17. storočia [Musikinventare und das Repertoire der mehrstimmigen Musik in der Slowakei im 16. und 17. Jahrhundert] (Musaeum Musicum). Bratislava: SNM-Hudobné múzeum, ${ }^{1} 1994$ ( $\left.{ }^{2} 1995\right)$, pp. 68-72. PETŐCZOVÁ, Janka. Prešovskí mestskí hudobníci v 17. storočí [The Musicians of the City Prešov/Eperies in the 17th Century], Slovenská hudba XIX, 1993, no. 3-4, pp. 364-365. 
pieces by Thomas Gosler, Johann Schimrack senior and Georg Wirsinger, preserved in the Levoća Lutheran Musical Collection have been published in a critical edition series titled Musica Scepusii Veteris (in the first, the second and the ninth series). This project is conceived as an open set of independent series presenting early music related to the area of Spiš/Zips county covering the Early Modern Period until the 19th century. Each volume consists of an analytical study (in Slovak and German languages), a facsimile of the primary source, a transcription of the composition from German organ tablature notation, and a revision report.

\section{Conclusion}

The musical life in urban centres of North-Eastern Slovakia can be studied as a model example for the historical musicology in Central Europe. The musical life in this territory has always been an integral part of a religiously and ethnically diverse cultural development; besides Germans and Slovaks, smaller communities of Ruthenians, Jews, Poles, Hungarians (Magyars) and Roma lived here. Though towns in Spiš and Šariš were rather small, their geographic location, advanced urbanisation and prospering commerce provided a relatively safe environment for musical life in the early modern period. Two musical societies - Fraternitas Litteratorum and Collegium Musicum - existed in Spišská Nová Ves in the 17th century, combining the German tradition of Lutheran municipal cantorates with multi-ethnic Slovak-German musical environment. The stable plurilingual Lutheran urban milieu made possible an extraordinary extension of the period of polyphonic and polychoral music till 1674, which took place during the period of Thirty Years' War and confessional fragmentation elsewhere in Europe. ${ }^{39}$

\section{Bibliography}

BAL, Jeromos - FÖRSTER, Jenő - KAUFFMANN, Aurél. Hain Gáspár Lốcsei Krónikája. Lőcse: Reiss Józs. T. Könyvnyomó Intézete, 1910-1913.

BURLAS, Ladislav - FIŠER, Ján - HOŘEJŠ, Antonín. Hudba na Slovensku v 17. storoč [The Music in Slovakia in the 17th Century]. Bratislava: Vydavatel'stvo SAV, 1954, pp. 99-103.

ČAPLOVIČ, Ján. Bibliografia tlač vydaných na Slovensku do roku 1700 [The Bibliography of the Prints in Slovakia until 1700], vol. 1. Martin: Matica slovenská, 1972.

Dejiny slovenskej hudby [The History of Slovak Music]. Bratislava: Vydavatel'stvo SAV, 1957, pp. 106-107.

39 This article is the result of project implementation Topography of Music in Slovakia in the Course of Centuries (No. 2/0050/17) supported by the Scientific Grant Agency of the Ministry of Education, Science, Research and Sport of the Slovak Republic and the Slovak Academy of Sciences, Bratislava, 2017-2020. The author works at the Institute of Musicology of the Slovak Academy of Sciences, Bratislava. The figures are reproduced with the kind permission of the archive Ministerstvo vnútra SR, Štátny archív v Prešove, Špecializované pracovisko Spišský archív v Levoči. 
Evanjelická encyklopédia Slovenska [The Lutheran Encyclopaedia of Slovakia]. Borislav Petrík - Peter Rybár (eds). Bratislava: BoPo, GBÚ ECAV, 2001.

EVANS, Robert J. W. Vznik habsburské monarchie 1550-1700 [The Making of the Habsburg Monarchy 1550-1700]. Translation: Lenka Kolářová. Praha: Argo 2003.

FRÖHLICH, David. Medulla geographiae practicae. Bartfeld 1639.

HULKOVÁ, Marta. Levočská zbierka hudobnín [Levoča Musical Collection], vol. I., II. Diss. Bratislava: FFUK, 1985.

HULKOVÁ, Marta. Von der Forschung der Musikgeschichte in der Slowakei. Orgel-Tabulaturbucher der Musikaliensammlungen von Levoča (17. Jahr.). Musaica 18. Bratislava: SPN, 1987, pp. 57-79.

HULKOVÁ, Marta. Rukopisné hlasové zošity Levočskej zbierky hudobnín (17. storočie) [The Handwritten Part-books of the Levoča Musical Collection (the 17th Century)]. Slovenská hudba 21, 1995, no. 2, pp. 203-227.

HULKOVÁ, Marta. Musikalische Handschriften aus der Wendezeit des 16. und 17. Jahrhunderts in der Musikaliensammlung von Levoča (Leutschau/Lőcse). In The Musical Heritage of the Jagiellonian Era. Paweł Gancarczyk, Agnieszka Leszczyńska (eds). Warszawa: Instytut Sztuki PAN, Uniwersytet Warszawski, Biblioteka Narodowa, 2012, pp. 253-267.

JEŻ, Tomasz. Łacińska twórczość muzyczna w ewangelickim Wrocławiu. Problem trwałości tradycji w czasach przemian konfesyjnych, Barok 2004, No 2, pp. clxxxv-ccv.

KAČIC, Ladislav. Od stredoveku po renesanciu. Barok [From the Middle Ages to the Renaissance. Baroque]. In Dejiny slovenskej hudby od najstaršich čias po súčasnost' [The History of Slovak Music from the ancient times to the present]. Oskár Elschek (ed.). Bratislava: Ústav hudobnej vedy SAV, ASCO Art et Science, 1996.

KOCH, Klaus-Peter. Das Claviertabulaturbuch von Caspar und Johannes Plotz. Bemerkungen zu Samuel Scheidt anhand der wieder aufgefundenen Handschrift Mus. ms. 40056 der ehemaligen Preußischen Staatsbibliothek Berlin. In Beiträge zur musikalischen Quellenforschung. Protokollband Nr. 2 der Kolloquien im Rahmen der Köstritzer Schütz-Tage 1988-1990. Bad Köstritz: Forschungs- und Gedenkstätte Heinrich-Schütz-Haus Bad Köstritz, 1991, pp. 229-243.

KOVÁČ, Dušan. Dejiny Slovenska (= Dejiny štátov) [The Short History of Slovakia (= The History of the States)]. Praha: Nakladatelství Lidové noviny, 1998.

KOWALSKÁ, Eva. Na d’alekých cestách, v cudzich krajinách: sociálny, kultúrny a politický rozmer konfesionálneho exilu z Uhorska v 17. storoči [On Long Journeys, in Foreign Countries: the Social, Cultural and Political Dimension of the 17th Century Confessional Exile from the Historical Hungarian Kingdom]. Bratislava: VEDA vydavatel'stvo SAV, 2014.

Krátke dejiny Slovenska [The Short History of Slovakia]. Elena Mannová (ed.). Bratislava: AEP, Historický ústav SAV, 2003.

LIPTÁK, Johann. Geschichte des evangelischen Distriktual-Lyzeums A. B. in Kesmark. KežmarokKesmark: Herausgegeben im Selbstverlage des Lyzealpatronates anläßlich der 400-Jahrfeier des Lyzeums, 1933.

MATÚŠ, František (ed.). Tabulatúrny zbornik Samuela Marckfelnera. Výber (= Stará hudba na Slovensku/Alte Musik in der Slowakei 4). Bratislava: OPUS, 1981.

[MATÚŠ, František.] Plotz, Gašpar (16./17.); Plotz, Ján (ca 1620-1680); Plotz, Juraj (ca 1610-1660). In Slovenský biografický slownik, vol. IV. Martin: Matica slovenská, 1990, p. 489.

MATÚŠ, František. De Musica Leonardi Stöckelii. Slovenská hudba 17, 1991, no. 4, pp. 360-416.

MATÚŠ, František. Príspevok k poznaniu vývinu hudobnoteoretického myslenia na Spiši v 16. storočí [A Contribution to the Knowledge of the Development of Music Theoretical Thinking in Spiš in the $16^{\text {th }}$ Century]. Musicologica Slovaca et Europaea 19, 1994, pp. 35-40. 
MURÁNYI, Róbert Árpád. Thematisches Verzeichnis der Musiksammlung von Bartfeld (Bártfa) (= Deutsche Musik im Osten 2) Bonn: Gudrun Schröder Verlag, 1991.

PETŐCZOVÁ, Janka. Polychorická hudba v levočskom rukopisnom zborníku sign. 74 A. [Polychoral Music in the Levoča/Leutschau Musical Manuscript shelfmark MUS A 74]. Hudebni věda XXV, 1988, No. 3, pp. 215-229.

PETŐCZOVÁ, Janka. Prešovskí mestskí hudobníci v 17. storočí [The Musicians of the City Prešov/ Eperies in the 17th Century]. Slovenská hudba XIX, 1993, no. 3-4, pp. 364-365.

PETÓCZOVÁ, Janka. Katalóg hudobnín farského kostola v Prešove z roku 1661. [Katalog der Musikalien der Pfarrkirche in Prešov aus dem Jahre 1661. In KALINAYOVÁ, Jana et al. Hudobné inventáre na Slovensku zo 16. a 17. storočia [Musikinventare und das Repertoire der mehrstimmigen Musik in der Slowakei im 16. und 17. Jahrhundert] (Musaeum Musicum). Bratislava: SNMHudobné múzeum, ${ }^{1} 1994\left({ }^{2} 1995\right)$, pp. 68-72.

PETŐCZOVÁ, Janka. Slovenský prvok v hudobnom živote Levoče v 17. storočí [The Slovak Element in the 17th Century Musical Life of Levoča/Leutschau]. Musicologica Slovaca et Europaea 19, 1994, pp. 63-78.

PETŐCZOVÁ, Janka. Leonard Stöckel a hudba [Leonard Stöckel and Music]. In Leonard Stöckel a reformácia v strednej Európe (= Acta Collegii Evangelici Prešoviensis XI). Peter Kónya (ed.). Prešov: Publishing House of the University of Prešov, 2011, pp. 70-84.

PETÓCZOVÁ, Janka. The Role of Silesia in the Development of Musical Culture in the Towns of Spiš/Zips and Šariš/Scharosch. In The Musical Culture of Silesia before 1742. New Contexts - New Perspectives (= Eastern European Studies in Musicology 1, M. Gołąb ed.). Paweł Gancarczyk Lenka Hlávková-Mráčková - Remigiusz Pośpiech (eds.). Frankfurt am Main: Peter Lang GmbH, 2013, pp. 161-178.

PETŐCZOVÁ-MATÚŠOVÁ, Janka (Ed.). Johann Schimrack / Ján Šimrák: Lobe den Herren, meine Seele! / Chvál, duša moja, Hospodina! [1642] (= Musica Scepusii Veteris II/1). Prešov: Prešovský hudobný spolok Súzvuk, 2004.

PETÓCZOVÁ, Janka. Hudba ako kultúrny fenomén v dejinách Spiša. Raný novovek [Music as a Cultural Phenomenon in the History of Zips. The Early Modern Period]. Bratislava: Ústav hudobnej vedy SAV, Prešovský hudobný spolok Súzuuk, 2014.

PETŐCZOVÁ, Janka. Šimrák versus Šimbracký. Mythen und Realität in der slowakischen Musikhistoriographie. Hudebni věda 52, no. 3-4, Praha 2015, pp. 273-316.

PRZYBYSZEWSKA - JARMIŃSKA, Barbara. BAROK, część pierwsza, 1595 - 1696 (= Historia Muzyki Polskiej III) Stefan Sutkowski (ed.). Warszawa: Sutkowski Edition, 2006.

RYBARIČ, Richard. Dejiny hudobnej kultúry na Slovensku I, Stredovek, renesancia, barok [The History of Musical Culture in Slovakia I, Middle Ages, Renaissance, Baroque]. Bratislava: OPUS, 1984. SZÓRÁDOVÁ, Eva. Všeobecnohistorické pramene v hudobnej historiografii [Allgemeinhistorische Quellen in die Musikhistoriographie]. In Ad honorem Richard Rybarič. Janka Petőczová (ed.) Bratislava: Ústav hudobnej vedy SAV, 2011, pp. 134-141. 
